\title{
DETECTION OF CALR EXON 9MUTATIONS IN EGYPTIAN PATIENTS WITH PERSISTENT THROMBOCYTOSIS
}

\section{Dalia Ahmed El-Sewefy, Gehan Mostafa Hamed, Yasmin Nabil Elsakhawy and Doha Osama Abdulrahman}

Clinical Pathology Department, Faculty of Medicine, Ain Shams University, Cairo, Egypt.

Corresponding author

Doha Osama Abdulrahman

Mobile: (+20) 1099623343

E.mail:

Dohaosama42@gmail.com

Received: 22/10/2020

Accepted: 25/11/2020

Online ISSN: 2735-3540

\begin{abstract}
:
Background: Thrombocytosis is a commonly encountered clinical scenario, with a large proportion of cases discovered incidentally when complete blood count is obtained for some unrelated reason, creating an important diagnostic challenge.
\end{abstract}

Aim of the Work: To evaluate the diagnostic and prognostic value of CALR mutations testing in patients with persistent thrombocytosis, and study the relation of thismutations with clinical and hematological parameters.

Patients and Methods: The present study included fifty patients with persistent thrombocytosis (platelet count $>450 \times 10^{9} / L$ ) for at least 3 months. All subjects were genotyped for the CALR gene using high resolution melting PCR (HRM-PCR) technique. The study was approved by the Research Ethics Committee of Ain Shams University.

Results: The present study revealed that CALR gene mutations are positive in one-third of cases with 1ry thrombocytosis. The mutations are associated with younger age males with higher platelet count, lower hemoglobin level and lower total leucocytic count (TLC) than CALR wild type counterparts.

Conclusion: The present study revealed that CALRexon 9 mutations can influence the clinical and hematological phenotype of the patient and hence the disease diagnosis and prognosis.

Keywords: Thrombocytosis- Primary-Reactive-CALR

\section{INTRODUCTION:}

Thrombocytosis is defined as elevated platelet count above $450 \times 10^{9} / \mathrm{L}$; this threshold was recommended by WHO and by the British Committee for Standards in Hematology (BCSH) (2010). In most literature, for thrombocytosis to be persistent, it should be sustained for at least 3 months $^{(1,2)}$.

The major causes of thrombocytosis can be divided into reactive and clonal thrombocytosis. Reactive causes include transient processes such as acute blood loss, acute infection or inflammation, extreme physical exertion, or other stress. Sustained forms of reactive thrombocytosis include iron deficiency, hemolytic anemia, asplenia, cancer, chronic inflammatory or infectious diseases, and rare drug reactions ${ }^{(\mathbf{3})}$.

Clonal thrombocytosis is typically due to a chronic myeloproliferative neoplasms (MPN) particularly essential thrombocytosis (ET) and pre- primary myelofibrosis (prePMF). These clonal disorders are associated with adverse events related to the thrombocytosis, including thrombotic, vascular and bleeding complications ${ }^{(3)}$.

According to the WHO classification of myeloid neoplasms (2016), CALR mutation is considered one of the major criteria for 
diagnosis of ET, pre-PMF and overt PMF. Therefore, many studies were directed to detect the frequency of this mutation in different disorders and ethnic groups as well as its impact on the patient's clinical phenotype and hence the prognosis ${ }^{(4)}$.

\section{AIM OF THE WORK:}

To evaluate the diagnostic and prognostic value of CALR mutations testing in patients with persistent thrombocytosis, and study the relation of this mutations with clinical and hematological parameters.

\section{PATIENTSAND METHODS:}

\section{I) Patients:}

The present study was conducted on 50patientswho attended Hematology and Oncology Unit of Ain Shams University Hospitals and referred to Main Hematology Lab in Clinical Pathology Department for investigation of persistent thrombocytosis (platelet count $>450 \times 10^{9} / \mathrm{L}$ ) during the period from July 2017 till July 2018.An informed oral consent was obtained from each participant before enrolment in the study. Moreover, the study was approved by the Research Ethics Committee of Ain Shams University.

\section{Inclusion Criteria:}

a) Adult Egyptian patients.

b) Persistent thrombocytosis (Platelet count $>450 \times 10^{9} / \mathrm{L}$ for more than 3 months).

\section{Exclusion criteria:}

A) Start of chemotherapy.

B) Diagnosis of BCR-ABL1 positive CML.

All individuals included in this study were subjected to the following:

- Full history taking.

- Thorough clinical examination, laying stress on organomegaly.
- Complete blood count (CBC) using LH 750 cell counter (Beckman Coulter, USA), with examination of Leishman stained peripheral blood smears.

- Bone marrow aspiration, with examination of Leishman stained bone marrow smears.

- Bone marrow trephine biopsy.

- Testing for exon 9 mutation of CALR by high resolution melting PCR (HRMPCR) using Rotor- Gene Q 5pex HRM (Qiagen, USA).

All patients were evaluated according to the criteria of ET and pre PMF in WHO classification of myeloid neoplasms (2016).

\section{II) Sampling}

A. A peripheral blood sample $(2 \mathrm{~mL})$ was collected on EDTA coated tubes from all enrolled patients and sent for CBC.

B. Bone marrow aspirate sample $(0.5 \mathrm{~mL})$ was withdrawn for creating bone marrow smears. Further $2 \mathrm{~mL}$ was withdrawn and collected on EDTA coated tube for DNA extraction, and detection of mutation. The extracted DNA was stored at $-20^{\circ} \mathrm{C}$.

\section{III) Methods:}

\section{A) Analytical Methods: CALR mutations detection:}

\section{1) Genomic DNA extraction:}

The DNA was extracted from fresh bone marrow or peripheral blood samples using QIAamp ® DNA Blood Mini kit (QIAGEN, USA).

\section{2) Detection of CALR Mutation by HRM PCR:}

The High-resolution melting PCR (HRM PCR) was done using the Type-it HRM PCR Kit (Qiagen, USA) on the Rotor-Gene Q 5pex HRM instrument (Qiagen, USA). The test primers were prepared by Applied Biosystems (USA). 
The reaction protocol started with initial cycle of pre incubation at $95^{\circ} \mathrm{C}$ for $10 \mathrm{~min}$, followed by 45 cycles of amplification composed of: heating at $95^{\circ} \mathrm{C}$ for $10 \mathrm{~s}$ (denaturation), heating at $64{ }^{\circ} \mathrm{C}$ for $10 \mathrm{~s}$ (annealing/extension) and finally heating at $74{ }^{\circ} \mathrm{C}$ (elongation). Then 1 cycle of high resolution melting composed of: heating at $95{ }^{\circ} \mathrm{C}$ for $60 \mathrm{~s}$ (denaturation), heating at $45{ }^{\circ} \mathrm{C}$ for $60 \mathrm{~s}$ (annealing), and finally heating 65-95 ${ }^{\circ} \mathrm{C}$ for $5 \mathrm{~s}$ (melting).

Data analysis was done using RotorGene Q Series Software 2.3.1 (Build 49). Data were presented in two formats: the normalized plot (Figure 1) and the difference plot (Figure 2).

The melting curves were normalized and temperature shifted creating the normalized plot which allows samples
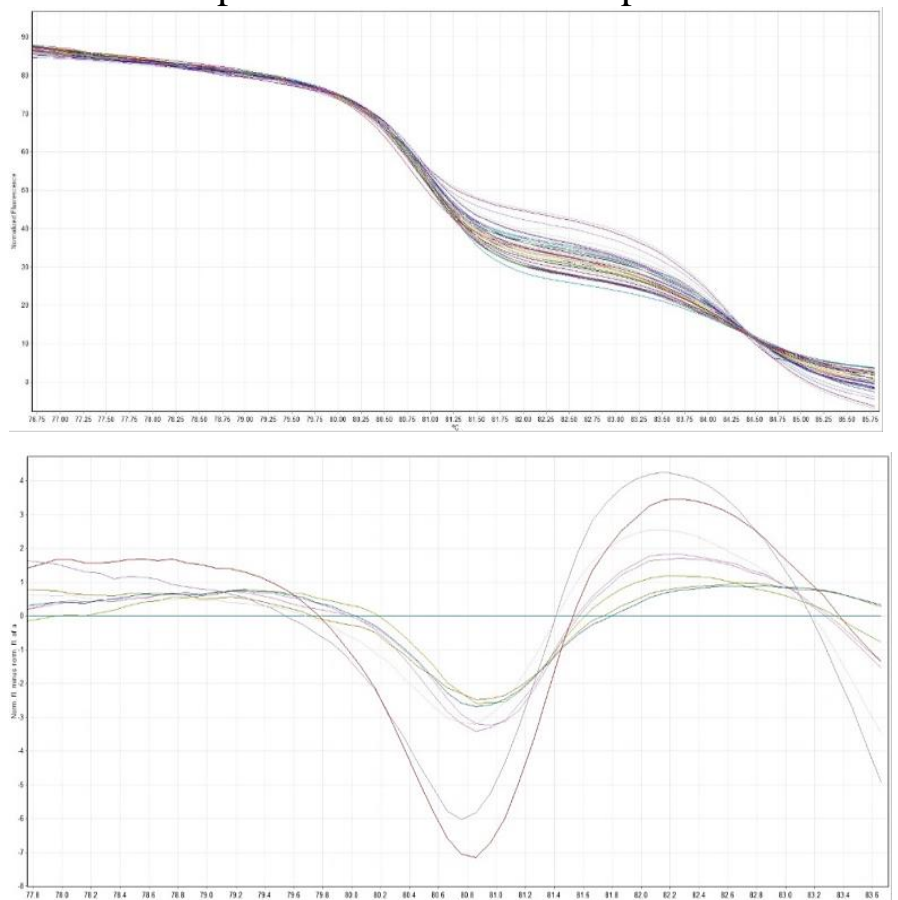

Figure (1): The normalized HRM PCR curves of the study patients

Figure (2): The difference curves showing CALR mutated samples, the baseline is the wild type control. to be directly compared. The normalized plot is the graph in which the amount of fluorescence (due to the intercalating dye remaining at any temperature point) is expressed as a fraction of the amount prior to data acquisition ${ }^{(5)}$.

Difference plots were generated by selecting a negative control as the baseline and the fluorescence of all other samples was plotted relative to this sample. Significant differences in fluorescence were indicative of mutations ${ }^{(5)}$. Each mutant allele had its own distinctive melting curve when compared to the wild-type allele. The distinct melting curves of the mutant became more apparent when data were represented in a difference plot format than in a normalized plot $^{(6)}$.

\section{B) Statistical Methods:}

- Sample size determination: the required sample size was calculated at the Community Department of Faculty of Medicine, Ain shams University using the $\mathrm{G}^{*}$ power software version 3.1 (Universität Düsseldorf, Germany).
The collected data were revised, coded, tabulated and introduced to Statistical Package for the Social Sciences soft-ware program (SPSS, version 25.0, IBM Corp., USA, 2017-2018). Data were presented and suitable statistical analysis was done according to the type of data obtained for each parameter. Qualitative data were 
expressed as number and percent (n; \%); parametric quantitative data were expressed as mean and standard deviation (SD). Comparative statistics for qualitative data was done by the Chi squared test $\left(\mathrm{X}^{2}\right)$ between two independent groups and the ANOVA test between three independent groups for qualitative data. As for quantitative parametric data, and Student's t test was performed. Probability or $\mathrm{p}$ value of $<0.05$ was considered statistically significant in all analyses.

\section{I- Overview of Study Group:}

The study group included 50 patients with sustained elevation in platelet count $\geq$ $450 \times 10^{3} / \mathrm{uL}$ for at least 3 months and was divided according to the WHO classification of myeloid neoplasms (2016) into: group A which involved 30 patients with 1ry thrombocytosis and group B that included 20 patients with reactive thrombocytosis.

\section{A- Epidemiological and clinical features:}

Group A comprised $16 \quad(53.3 \%)$ females and 14 (46.7\%) males. Their ages ranged from 19 to 72 with a mean of $49.03 \pm$ 15.05 yrs. At presentation, 17 (56.7\%) had organomegaly. As regard group $\mathbf{B}$, it comprised 9 females $(45 \%)$ and 11 males $(55 \%)$. Their ages ranged from 17-78 with a mean of $45.05 \pm 16.78$ yrs. At presentation, 2 $(10 \%)$ had organomegaly.

\section{B- Routine laboratory Data:}

In group $\mathrm{A}$, the total leucocytic count (TLC) ranged from 4.7 to $35.9 \times 10^{3} / \mathrm{uL}$, hemoglobin $(\mathrm{Hb})$ showed a mean of $12.25 \pm$ $2.63 \mathrm{~g} / \mathrm{dL}$, platelet count ranged from 455 to $2617 \times 10^{3} / \mathrm{uL}$ and mean platelet volume (MPV) showed a mean of $9.8 \pm 1.5$ and ranged from 8 to 13.2 .

In group B, TLC ranged from 6.8 to $33.3 \times 10^{3} / \mathrm{uL}, \mathrm{Hb}$ showed a mean of $9.9 \pm$ $3.6 \mathrm{~g} / \mathrm{dL}$, platelet count ranged from 536 to $1315 \times 10^{3} / \mathrm{uL}$ and MPV showed a mean of $9.6 \pm 1$ and ranged from 8.5 to 12 .

Regarding group A, 9 patients out of 30 (30\%) were positive for CALR mutation. In group $\mathrm{B}$, all the studied patients were negative for CALRmutation.

\section{Comparison betweengroup A and group} B

\section{Epidemiological and clinical features (Table1)}

A higher incidence of organomegaly and thrombotic events was detected in group A reaching a highly significant (HS) difference $(p=0.001)$. In contrast, no significant difference was revealed as regard age and gender $(\mathrm{p}<0.05)$.

Table (1): Epidemiological and clinical features of both groups (A \& B)

\begin{tabular}{|c|c|c|c|c|c|}
\hline \multirow[t]{2}{*}{ Variable } & Group A & Group B & \multirow[t]{2}{*}{ Test value } & \multirow[t]{2}{*}{ P-value } & \multirow[t]{2}{*}{ Sig } \\
\hline & $n=30$ & $n=20$ & & & \\
\hline \multirow{2}{*}{$\begin{array}{l}\text { Age (years), Mean } \pm \text { SD } \\
\text { (Range) }\end{array}$} & $49.03 \pm 15.05$ & $45.05 \pm 16.78$ & \multirow[t]{2}{*}{$0.876^{\bullet}$} & \multirow[t]{2}{*}{0.385} & \multirow[t]{2}{*}{ NS } \\
\hline & $19-72$ & $17-78$ & & & \\
\hline \multicolumn{6}{|l|}{ Gender, n (\%) } \\
\hline Female & $16(53.3)$ & $9(45)$ & \multirow[t]{2}{*}{$0.333^{*}$} & \multirow[t]{2}{*}{0.564} & \multirow[t]{2}{*}{ NS } \\
\hline Male & $14(46.7)$ & $11(55)$ & & & \\
\hline \multicolumn{6}{|l|}{ Organomegally. n (\%) } \\
\hline No & $13(43.3)$ & $18(90)$ & $11.092 *$ & 0.001 & HS \\
\hline Yes & $17(56.7)$ & $2(10)$ & & & \\
\hline \multicolumn{6}{|l|}{ Thrombosis, n (\%) } \\
\hline No & $18(60)$ & $20(100)$ & $10.526 *$ & 0.001 & $\mathrm{HS}$ \\
\hline Yes & $12(40)$ & $0(0)$ & & & \\
\hline
\end{tabular}

P-value >0.05: Non significant (NS); P-value <0.05: Significant (S); P-value < 0.01: highly significant (HS) $*:$ Chi-square test; $\bullet$ : Independent t- test. 
Routine Laboratory Data (Table 2):

Hemoglobin level showed significant difference $(\mathrm{p}=0.01)$, being lower in group $\mathrm{B}$.
No statistically significant difference regarding other different laboratory data.

Table (2): Comparison between group A and group B regarding routine laboratory data

\begin{tabular}{|l|l|c|c|c|c|c|}
\hline \multicolumn{2}{|c|}{} & Group A & Group B & \multirow{2}{*}{ Test value } & \multirow{2}{*}{ P-value } & Sig. \\
\cline { 3 - 5 } \multicolumn{2}{l|}{} & n= 30 & $\mathbf{n = 2 0}$ & & & \\
\hline TLCs & Range & $4.7-35.9$ & $6.8-33.3$ & $-1.011 \bullet$ & 0.317 & NS \\
\hline Granulocytes & Range & $0.9-33.5$ & $4-26.5$ & $-0.756 \bullet$ & 0.453 & NS \\
\hline RBCs & Range & $2.5-7.9$ & $2.3-7.13$ & $1.226 \bullet$ & 0.226 & NS \\
\hline Hb & Range & $7.6-17.8$ & $4.1-17.9$ & $2.684 \bullet$ & 0.010 & S \\
\hline Hct & Range & $22.8-55.3$ & $14.3-52.5$ & $1.934 \bullet$ & 0.059 & NS \\
\hline MCV & Range & $48.4-108$ & $55.7-87.9$ & $1.232 \bullet$ & 0.224 & NS \\
\hline MCH & Range & $14.3-32.9$ & $14.5-28.5$ & $1.292 \bullet$ & 0.203 & NS \\
\hline MCHC & Range & $28.9-38$ & $24.5-38.7$ & $0.876 \bullet$ & 0.385 & NS \\
\hline RDW & Range & $13.4-26$ & $12.4-40.1$ & $-0.442 \bullet$ & 0.661 & NS \\
\hline PLTs & Range & $455-2617$ & $536-1315$ & $0.871 \bullet$ & 0.388 & NS \\
\hline MPV & Range & $8-13.2$ & $8.5-12$ & $0.584 \bullet$ & 0.562 & NS \\
\hline LDH & Range & $100-832$ & $100-756$ & $-0.951 \neq$ & 0.342 & NS \\
\hline
\end{tabular}

TLC: total leucocytic count, RBCs: red blood cells, Hb: hemoglobin, Hct: hematocrit, $\mathrm{MCV}$ :mean corpuscular volume, $\mathrm{MCH}$ : mean corpuscular hemoglobin, MCHC: mean corpuscular hemoglobin concentration, RDW: red cell distribution width, PLTs: platelets, MPV: mean platelet volume, LDH: lactate dehydrogenase, P-value $>0.05$ : Non significant (NS); P-value <0.05: Significant (S); P-value< 0.01: highly significant (HS): *:Chi-square test;

$\bullet$ Independent t-test; + : Mann Whitney test

CALR mutation status (figure 3):

As for the mutation status there was a significant difference regarding $C A L R$ mutation ( $\mathrm{p}=0.018$ ) being positive in 1ry thrombocytosis (group A).

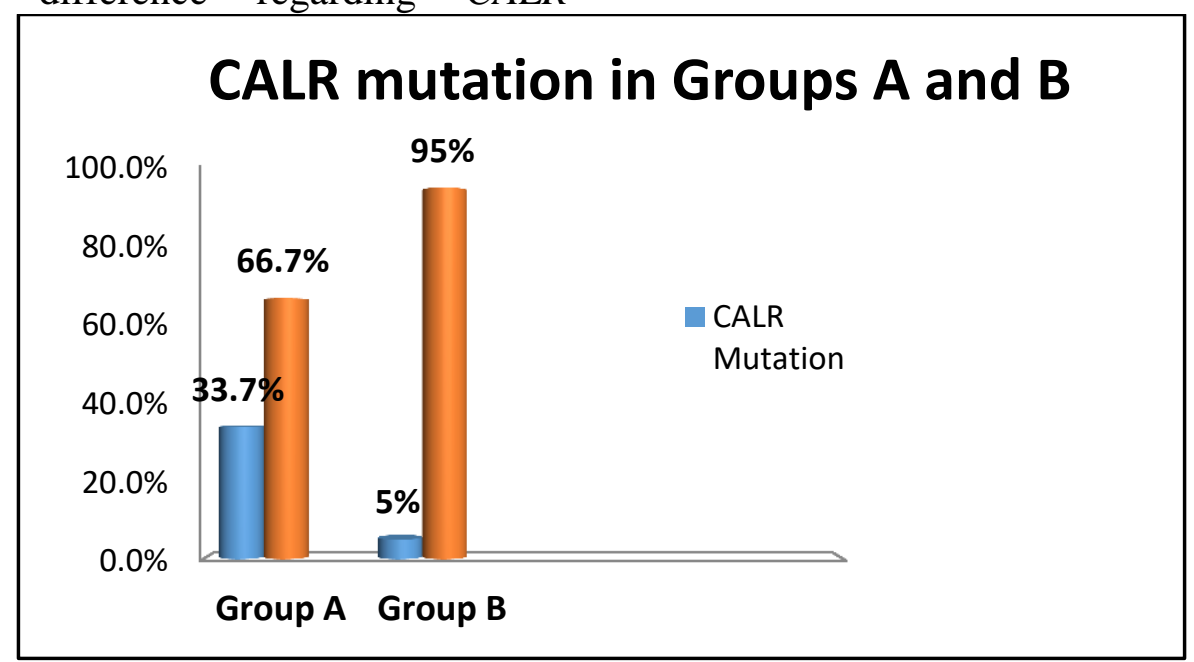

Figure (3): Frequency of CALR mutation in groups A \& B.

III. Comparison between patients with 1ry thrombocytosis regarding CALR mutation
As shown in Table 3, CALR mutation were significantly higher among younger males $(\mathrm{p}<0.05)$. 
Laboratory data showed, lower TLC, lower $\mathrm{Hb}$ and higherplatelet count $(\mathrm{p}<0.05)$ among 1ry thrombocytosis patients with
CALR mutation. No significant difference was found regarding Hct, $\mathrm{MCV}$ or $\mathrm{MCH}$ $(\mathrm{p}>0.5)$.

Table (3): Comparison between patients with mutated and unmutated CALR

\begin{tabular}{|c|c|c|c|c|c|c|}
\hline & $\begin{array}{l}\text { Negative CALR } \\
\text { mutation }\end{array}$ & $\begin{array}{l}\text { Positive CALR } \\
\text { mutation }\end{array}$ & \multirow[t]{2}{*}{ Test value } & \multirow[t]{2}{*}{ P-value } & \multirow[t]{2}{*}{ Sig. } \\
\hline & & $\mathrm{n}=20$ & $\mathrm{n}=10$ & & & \\
\hline \multirow[t]{2}{*}{ Age } & Mean \pm SD & $53.60 \pm 14.02$ & $39.90 \pm 13.24$ & \multirow[t]{2}{*}{$2.568 \bullet$} & \multirow[t]{2}{*}{0.016} & \multirow[t]{2}{*}{ S } \\
\hline & Range & $26-72$ & $19.0-60.0$ & & & \\
\hline \multirow[t]{2}{*}{ Sex } & Female & $14(70.0 \%)$ & $2(20.0 \%)$ & \multirow[t]{2}{*}{$6.696^{*}$} & \multirow[t]{2}{*}{0.010} & \multirow[t]{2}{*}{ S } \\
\hline & Male & $6(30.0 \%)$ & $8(80.0 \%)$ & & & \\
\hline \multirow[t]{2}{*}{ TLCs } & Mean \pm SD & $15.51 \pm 7.84$ & $8.89 \pm 2.73$ & \multirow[t]{2}{*}{$2.572 \bullet$} & \multirow[t]{2}{*}{0.016} & \multirow[t]{2}{*}{$\mathrm{S}$} \\
\hline & Range & $9-35.9$ & $4.7-12.7$ & & & \\
\hline \multirow[t]{2}{*}{$\mathrm{RBCs}$} & Mean \pm SD & $5.10 \pm 1.12$ & $3.79 \pm 1.59$ & \multirow[t]{2}{*}{$2.616^{\bullet}$} & \multirow[t]{2}{*}{0.014} & \multirow[t]{2}{*}{$S$} \\
\hline & Range & $3.9-7.4$ & $2.5-7.9$ & & & \\
\hline \multirow[t]{2}{*}{$\mathrm{Hb}$} & Mean \pm SD & $12.96 \pm 2.15$ & $10.84 \pm 3.04$ & \multirow[t]{2}{*}{$2.208 \bullet$} & \multirow[t]{2}{*}{0.036} & \multirow[t]{2}{*}{$\mathrm{S}$} \\
\hline & Range & $10.2-17.8$ & $7.6-17.4$ & & & \\
\hline \multirow[t]{2}{*}{ Hct } & Mean \pm SD & $38.92 \pm 8.21$ & $32.55 \pm 9.20$ & \multirow[t]{2}{*}{$1.926^{\bullet}$} & \multirow[t]{2}{*}{0.064} & \multirow[t]{2}{*}{ NS } \\
\hline & Range & $23.7-55.3$ & $22.8-52.5$ & & & \\
\hline \multirow[t]{2}{*}{ MCV } & Mean \pm SD & $76.14 \pm 12.48$ & $81.38 \pm 10.32$ & \multirow[t]{2}{*}{$-1.144 \bullet$} & \multirow[t]{2}{*}{0.262} & \multirow[t]{2}{*}{ NS } \\
\hline & Range & $48.4-108$ & $65.1-93.3$ & & & \\
\hline \multirow[t]{2}{*}{$\mathrm{MCH}$} & Mean \pm SD & $24.19 \pm 4.30$ & $26.55 \pm 3.91$ & \multirow[t]{2}{*}{$-1.461 \bullet$} & 0.155 & NS \\
\hline & Range & $14.3-32.9$ & $19.4-30.4$ & & & \\
\hline $\mathrm{MCHC}$ & Mean \pm SD & $31.73 \pm 1.95$ & $32.55 \pm 2.36$ & $-1.012 \bullet$ & 0.320 & NS \\
\hline & Range & $28.9-34.9$ & $29.8-38.0$ & & & \\
\hline RDW & Mean \pm SD & $19.24 \pm 3.58$ & $18.81 \pm 3.66$ & $0.308 \bullet$ & 0.761 & NS \\
\hline & Range & $13.4-26$ & $13.7-25.9$ & & & \\
\hline PLTs & Mean \pm SD & $763.30 \pm 199.90$ & $1330.90 \pm 604.73$ & $-3.853 \bullet$ & 0.001 & HS \\
\hline & Range & $455-1085$ & $788.0-2617.0$ & & & \\
\hline & Yes & $11(55.0 \%)$ & $1(10.0 \%)$ & & & \\
\hline
\end{tabular}

TLC: total leucocytic count, RBCs: red blood cells, Hb: hemoglobin, Hct: hematocrit, MCV: mean corpuscular volume, MCH: mean corpuscular hemoglobin, MCHC: mean corpuscular hemoglobin concentration, RDW: red cell distribution width, PLTs: platelets, MPV: mean platelet volume,

P-value >0.05: Non significant (NS); P-value <0.05: Significant (S); P-value < 0.01: highly significant (HS)

*:Chi-square test; $\bullet:$ Independent t-test; $\$$ : Mann Whitney test

\section{DISCUSSION:}

Thrombocytosis is a commonly encountered clinical scenario, with a large proportion of cases discovered incidentally. It is defined as elevated platelet count above $450 \times 10^{9} / \mathrm{L} ;$ this threshold was recommended by WHO (2016) and by the British Committee for Standards in Hematology (BCSH) (2010). In most literature, for thrombocytosis to be persistent, it should be sustained for at least 3 months ${ }^{(1,2,7)}$.

The major causes of thrombocytosis can be divided into reactive and clonal thrombocytosis. Reactive causes include transient processes such as acute blood loss, acute infection or inflammation, extreme physical exertion, or other stress. Sustained forms of reactive thrombocytosis include iron deficiency, hemolytic anemia, asplenia, 
cancer, chronic inflammatory or infectious diseases, and rare drug reactions ${ }^{(\mathbf{3})}$.

Clonal thrombocytosis is typically due to a chronic MPN particularly ET and prePMF. According to the WHO classification of myeloid neoplasms (2016), CALR mutation is considered one of the major criteria for diagnosis of ET, pre-PMF and overt $\mathrm{PMF}^{(4)}$.

The aim of the present study was to detect CALR gene mutations in patients with persistent thrombocytosis and to discover the relation of these mutations with clinical and hematological parameters.

The results of the present study showed that CALR mutations were observed in $30 \%$ of ET cases. Overall, these mutational frequencies accord well with the findings of other studies $\left.{ }^{(\mathbf{8 , 9}}\right)$.

Wealso noticed that 1ry thrombocytosis cases having CALR mutation were younger males, with lower hemoglobin level and higher platelet count compared with cases lacking CALR mutation. These findings were described also by Bilbao-Sieyro et al. $\mathbf{( 2 0 1 4 )}^{(10)}$ and by Marty et al. $(2016)^{(11)}$.

Of note, almost all the studied patients with reactive thrombocytosis didn't reveal to harbor the CALR mutation which accords with the findings reported by Bilbao-Sieyro et al. $(2014)^{(10)}$.

In conclusion, detection of CALR mutations in cases of persistent thrombocytosis could help distinguishing 1ry and 2ry thrombocytosis and might uncover the presence of ongoing clonal disorder. It also could help in predicting the clinical phenotype and disease outcome of patients with persistent thrombocytosis. Eventually, detection of CALR mutation by HRM- PCR could be used as a screening test saving time and money, and then the positive samples are to be validated and further identified by sequencing techniques.

\section{REFERENCES}

1. Brière JB (2007): Essential thrombocythemia. Orphanet Journal of Rare Diseases; 2(3): 1-17.

2. Kucine N, Chastain KM, Mahler MB, et al. (2014): Primary thrombocytosis in children. Haematologica;99 (4): 620-628.

3. Schafer A (2015): Thrombocytosis. Clinical Review\& Education JAMA Diagnostic Test Interpretation; 314(11): 1171-1172.

4. Misawa K, Yasuda H, Araki M. (2018): Mutational subtypes of JAK2 and CALR correlate with different clinical features in Japanese patients with myeloproliferative neoplasms. International Journal of Hematology; 107(6): 673-680.

5. Matsumoto N, Mori S, Hasegawa H, et al., (2016): Simultaneous screening for JAK2 and calreticulin gene mutations in myeloproliferative neoplasms with high resolution melting. Clinica Chimica Acta; 462(1): 166-173.

6. Li J, Kent DG, Godfrey AL, et al. (2014): JAK2V617F homozygosity drives a phenotypic switch in myeloproliferative neoplasms, but is insufficient to sustain disease. Blood;123(20): 3139-3151.

7. Natelson E A (2012): Extreme Thrombocytosis and Cardiovascular Surgery. Texas Heart Institute Journal; 39(6): 792-798.

8. Klampfl T, Gisslinger H, Harutyunyan AS, et al. (2013): Somatic mutations of calreticulin in myeloproliferative neoplasms. New England Journal of Medicine; 369(25): 2379-2390.

9. Nangalia J, Massie CE, Baxter EJ et al. (2013): Somatic CALR mutations in myeloproliferative neoplasms with nonmutated JAK2. New England Journal of Medicine; 369(25): 2391-2405.

10. Bilbao-Sieyro C, Santana G, Moreno M, et al. (2014): High Resolution Melting Analysis: A Rapid and Accurate Method to Detect CALR Mutations. PLOS ONE;9(7): e103511. 
11. Marty $\mathrm{C}$, Pecquet $\mathrm{C}$, Nivarthi $\mathrm{H}$, et al. (2016): Calreticulin mutants in mice induce an MPL-dependent thrombocytosis with frequent progression to myelofibrosis. Blood; 127(10): 1317-1324.

\section{الكثف عن الطقرات الجينية للكالريتكيولين اكسون 9 في المرضى المصريين المصابين بالزيادة المستمرة في عدد الصفائح الاموية المرفى \\ داليهاحمد السويفي , جيهان مصطفى حامد , ياسمين نبيل السخاوي

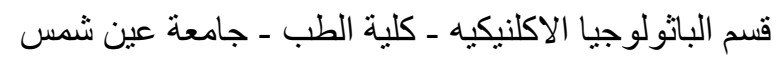

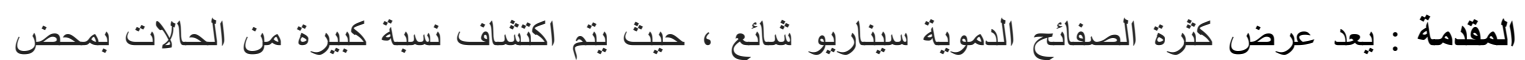

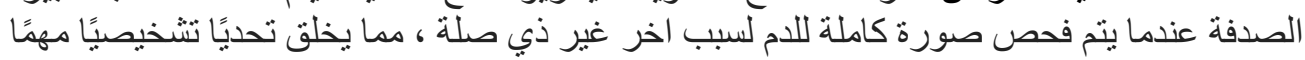

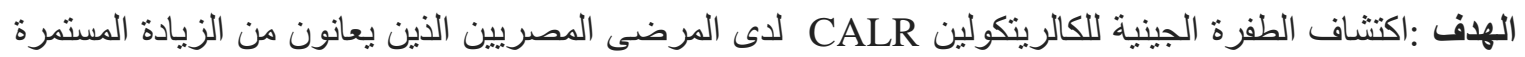

في عدد الصفائح الدموية, بالاضافة الى تقييم العلاقة بين هذه الطفرة و الصفات الاكلينيكية وبيانات الدم المعطلية للمرضى. لإنى

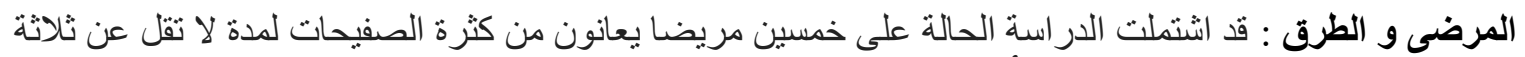

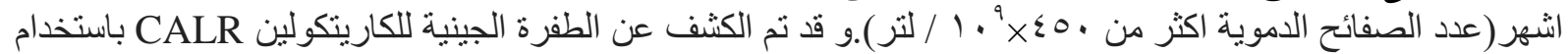
تقنية الذوبان عالية الدقة (HRM-PCR). تمت المو افقة على الدر اسة من قبل لجنة أخلاقيات البحث العلمي بجامعة عين

النتائج : نم اكتشاف وجود الطفرة الجينية للكارليتكولينCALR في ثلث عددالمرضى المصابين بزيادة الصفائح

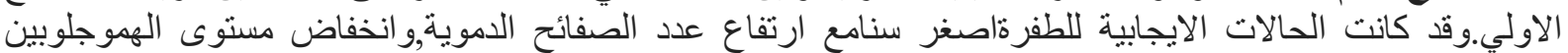

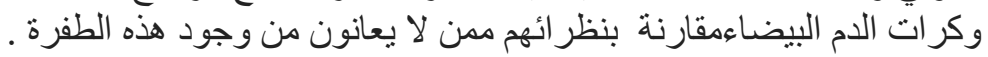

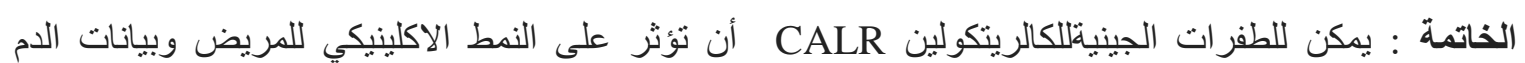

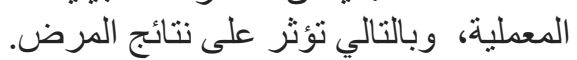

